\title{
TINGKAT PENGETAHUAN PETERNAK KAMBING PERAH TERHADAP PENYAKIT ZOONOSIS STUDI KASUS “KELOMPOK TANI TERNAK SYMPAY TAMPOMAS”
}

\author{
Tyagita Hartady ${ }^{1,2}$, Rini Widyastuti ${ }^{1,3, *}$, dan Mohammad Ghozali ${ }^{2}$ \\ ${ }^{1}$ Program Studi Kedokteran Hewan, Fakultas Kedokteran, Universitas Padjadjaran \\ ${ }^{2}$ Departemen Ilmu Kedokteran Dasar, Fakultas Kedokteran, Universitas Padjadjaran \\ ${ }^{3}$ Laboratorium Reproduksi dan Inseminasi Buatan, Departemen Produksi Ternak, Fakultas Peternakan, Universitas Padjadjaran \\ E-mail: widyastuti25@gmail.com
}

\begin{abstract}
ABSTRAK. Hubungan antara peternak, hewan ternak, dan lingkungan sangat signifikan sehingga diperlukan studi untuk mengetahui hubungan ketiga komponen tersebut terhadap penyakit zoonosis. Kegiatan diawali dengan menilai keadaan umum lingkungan peternakan dan kondisi kambing perah melalui tanya jawab berbagai faktor risiko penyakit zoonosis, penyuluhan kepada peternak mengenai penyakit-penyakit yang umum menyerang kambing perah dan pentingnya pengelolaan kesehatan kambing perah. Sebanyak $75 \%$ peternak telah membuat kandang kambing dengan model panggung, beralas bambu, serta memiliki kisi-kisi di dindingnya untuk memudahkan perputaran udara, 25\% kandang lainnya dibuat dengan model terbuka dan kambing langsung kontak dengan lantai. Jarak antar kandang di daerah ini umumnya tidak saling berdekatan. Di sisi lain, 16,7 \% peternak merupakan kelompok peternak berumur lebih dari 47 tahun dan beresiko tinggi terhadap infeksi penyakit. Sedangkan 16,7\% peternak mengerti tentang penyakit zoonosis dari kambing ke manusia didukung dengan rendahnya upaya peternak dalam melakukan tindakan pencegahan terhadap infeksi zoonosis. Sebanyak $83,3 \%$ peternak cenderung tidak melakukan pencegahan terjadinya penyakit zoonosis. Mengenai perawatan kesehatan kambing, rata-rata $48 \%$ peternak tidak melakukan tindakan-tindakan pencegahan penyakit infeksi pada kambingnya. Kondisi ini berpotensi menyebabkan kambing terjangkit penyakit dan tidak menutup kemungkinan menular ke ternak lainnya atau ke peternak.
\end{abstract}

Kata kunci: Peternak; zoonosis; penyakit; kambing; Sumedang.

ABSTRACT. The relationship between farmers, livestock, and the environment is so significant that studies are needed to know the relationship of these three components to zoonotic diseases. The activity begins with assessing general state of the environment and the condition of dairy goats through question and answer. Questionnaires were conducted by asking various risk factors for zoonotic disease and extension to farmers about common diseases that attacked the animal and the importance of animal health management. As many as $75 \%$ of breeders have made goat cages with stage models, bamboo-shaped, and have a grille on the wall to facilitate air rotation, $25 \%$ other made with open models and goats contact the floor directly. The distance between stalls is generally not close to each other. A total of $16.7 \%$ of breeders are groups of farmers aged over 47 years and are at high risk of infection. While $16.7 \%$ of farmers understand about zoonotic disease supported by low efforts of farmers in taking precautions against zoonotic infection. As many as $83.3 \%$ of farmers tend not to prevent zoonotic diseases. Regarding goat health care, an average of $48 \%$ of farmers do not prevent infectious diseases in their goats. This condition potentially causes goats infected and possible in transmitting to other livestock or to farmers.

Key words: Farmer; zoonosis; disease; goat; Sumedang.

\section{PENDAHULUAN}

Indonesia merupakan negara tropis dengan kondisi alam yang baik untuk perkembangan kambing perah. Salah satu daerah dengan jumlah populasi kambing perah yang cukup tinggi yakni desa Cibeureum Wetan, Kabupaten Sumedang. Kondisi alam dan luasnya lahan penghasil pakan ternak di wilayah tersebut merupakan faktor penunjang keberhasilan pemeliharaan kambing perah (Widyastuti et al., 2017). Hal ini dapat berpotensi menguntungkan secara ekonomis sehingga dapat dimanfaatkan oleh peternak kambing perah untuk menghasilkan produk bernilai jual, seperti susu dan daging. Dengan harapan dapat menghasilkan produk-produk berkualitas, para peternak kambing perah tentu harus dapat menjaga kesejahteraan baik kambingnya maupun dirinya sehingga kambing perah dapat terus sehat dan menghasilkan produk-produk berkualitas. Kesejahteraan kambing dan peternak turut dipengaruhi oleh interaksi intensitas tinggi antara manusia dan hewan ternaknya. Interaksi hewan ternak dan peternak ialah hubungan timbal balik sehingga keadaan hewan ternak menjadi suatu faktor penentu kesehatan yang signifikan terhadap peternak, begitu pula sebaliknya. Di sisi lain, lingkungan kandang juga memiliki peran penting sebagai sarana tempat terjadinya interaksi antara hewan ternak dan peternak. Kandang yang ideal dapat membantu meminimalisir transmisi penyakit zoonosis, akan tetapi sebaliknya bila kondisi kandang tidak memenuhi standar kandang ideal (CDC, 2017). Hubungan antara peternak, hewan ternak, dan lingkungan ini sangat signifikan sehingga tidak dapat dipisahkan. Dalam rangka peningkatan kesejahteraan hewan ternak dan peternak di Indonesia, tentu ketiga komponen ini harus ditelusuri lebih lanjut. Diharapkan hasil telusuran tersebut dapat menunjukkan hubungan ketiga komponen tersebut dengan munculnya gejala-gejala penyakit infeksi yang dapat mengancam kesejahteraan atau kualitas hidup dari hewan ternak dan peternak. Untuk menelusuri hubungan ini, akan dilakukan pengambilan data melalui kuesioner untuk mengetahui jenis penyakit apa saja yang umum dialami peternak dan hewan ternak di daerah tersebut serta mengetahui sejauh mana pengetahuan peternak terkait bahaya suatu penyakit pada hewan ternak dan bagaimana cara mencegahnya. Selain itu, kami pun berupaya untuk 
memberikan suatu edukasi berupa penyuluhan dan pembelajaran yang lebih komprehensif mengenai pentingnya menjaga kesehatan ternak. Dengan demikian, diharapkan dapat menjadi dasar untuk meningkatkan kewaspadaan adanya penyakit menular dari manusia ke hewan dan sebaliknya, sehingga akan membantu peternak mencegah timbulnya berbagai macam penyakit ternak yang pada akhirnya beresiko menimbulkan kerugian ekonomi.

\section{METODE}

Kegiatan pengabdian dilaksanakan sejak bulan Juli sampai dengan November 2017 dengan melibatkan Kelompok Peternak Kambing Peranakan Ettawa Simpay Tampomas yang berlokasi di lereng Gunung Tampomas, Cimalaka, Sumedang, Jawa Barat. Kelompok ini didirikan pada tahun 1998 dan telah memanfaatkan lahan kritis bekas galian pasir untuk ditanami leguminosa sehingga mempercepat reklamasi lahan di area tersebut. Populasi ternak kambing perah cukup banyak sekitar 400 ekor dan dikelola oleh 35 kepala keluarga. Pengelolaan masih tradisional dan kurang memperhatikan Good Farming Practice (Yunita et al., 2017). Susu yang diproduksi diolah dan dikelola secara sederhana tanpa ada sentuhan teknologi. Namun demikian, masyarakat di daerah tersebut memiliki antusiasme yang cukup tinggi untuk belajar mengelola ternak secara terpadu.

Kegiatan diawali dengan menilai keadaan umum daerah tersebut yang mencakup lingkungan kandang dan kondisi kambing perah melalui tanya jawab dengan peternak. Kuesioner mengenai penelaahan infeksi zoonosis dilakukan dengan menanyakan berbagai faktor risiko yang terdiri dari status demografis peternak Knowledge, Attitude, and Practice (KAP) yang dijabarkan menjadi kontak sehari-hari peternak dengan kambing perah, pengkajian pengetahuan penyakit zoonosis dan kesehatan ternak kambing ternak. Berdasarkan hasil kuesioner yang diperoleh, kami lanjutkan dengan melakukan penyuluhan kepada para peternak mengenai penyakit-penyakit yang umum menyerang dan pentingnya pengelolaan kesehatan kambing perah melalui penerapan sanitasi kandang dan lingkungan serta pemberian pakan yang baik. Hasil pengamatan tersebut kami jadikan sebagai data lapangan yang akan kami olah dan kelak akan kami paparkan dalam penyuluhan kesehatan.

\section{HASIL DAN PEMBAHASAN}

Berdasarkan kuesioner yang diberikan, diperoleh hasil bahwa kondisi perkandangan di daerah peternakan Kelompok Tani “cukup variatif". Tujuh puluh lima persen peternak telah membuat kandang kambing dengan model panggung, beralas bambu, serta memiliki kisikisi di dindingnya untuk memudahkan perputaran udara,
$25 \%$ kandang lainnya dibuat dengan model terbuka dan kambing langsung kontak dengan lantai. Jarak antar kandang di daerah ini umumnya tidak saling berdekatan.

Hasil kuesioner menunjukkan rata-rata usia peternak adalah 47 tahun dengan rasio seperti terlihat pada Gambar 1. Hal ini menunjukkan bahwa terdapat $16,7 \%$ peternak merupakan kelompok peternak berumur lebih dari 47 tahun dan beresiko tinggi terhadap infeksi penyakit. Data yang diperoleh dari Centers for Disease Control and Prevention (CDC) tahun 2005, beberapa orang yang berisiko lebih tinggi untuk terinfeksi beberapa penyakit tertentu, yakni anak-anak bawah lima tahun (balita), orang dengan keadaan immunocompromised, serta lanjut usia (lansia) lebih dari 65 tahun. Dari data di lapangan, baik wanita maupun pria berusia di bawah 47 tahun cenderung lebih tahan terhadap infeksi penyakit zoonosis mengingat daya kondisi dan daya tahan tubuh yang lebih tinggi dibandingkan dengan peternak yang berusia di atas 47 tahun. Gambar 1. menjelaskan bahwa jumlah kelompok rentan infeksi zoonosis dari kambing perah piaraan banyak mengancam wanita berusia lanjut diikuti dengan pria dari kelompok usia yang sama dibandingkan dengan pria dan wanita dari kelompok usia relatif lebih muda. Data di lapangan merupakan refleksi dari informasi yang telah dinyatakan oleh CDC (2005).

Adanya suatu penyakit menular dapat diakibatkan

Perbandingan Usia terhadap Infeksi Penyakit Zoonosis

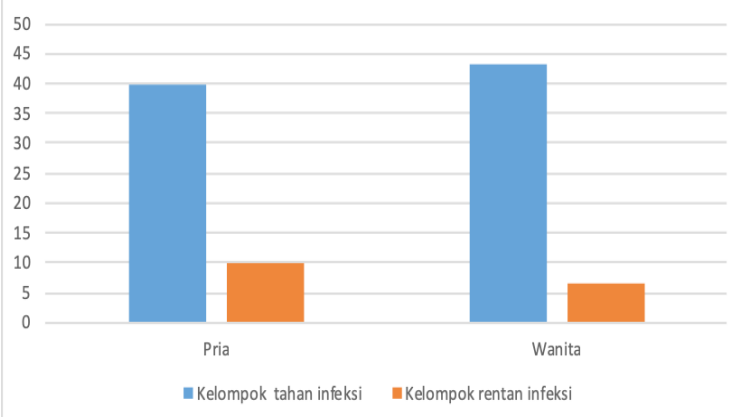

Gambar 1. Perbandingan usia mempengaruhi kerentanan terhadap infeksi penyakit zoonosis dari ternak kambing yang dipelihara.

karena kurangnya informasi tentang tata cara upaya pencegahannya (Klous et al., 2016). Dari data di lapangan diketahui hanya $16,7 \%$ peternak yang mengerti tentang penyakit zoonosis dari kambing ke manusia. Hal ini berbanding lurus dengan rendahnya upaya peternak dalam melakukan tindakan pencegahan terhadap infeksi zoonosis seperti menggunakan alat pelindung diri saat memerah susu. Nyatanya, semua peternak melakukan kontak langsung dengan ternaknya setiap hari (Tabel 1.). Akan tetapi, mereka dapat menangani beberapa penyakit tertentu secara empiris meskipun tidak mengetahui jenis penyakitnya. Mereka pun cenderung untuk membawa ternak mereka pada mantri, dokter hewan, atau ke peternak lain yang dianggap lebih paham bila kambing mereka terlihat sakit. 
Tabel 1. Menggambarkan usaha-usaha preventif timbulnya penyakit zoonosis yang dilakukan peternak.

\begin{tabular}{clc}
\hline No. & \multicolumn{1}{c}{ Upaya Pencegahan Infeksi } & Persentase \\
\hline 1. & $\begin{array}{l}\text { Pengetahuan tentang penyakit zoonosis/ } \\
\text { menular dari kambing ke manusia }\end{array}$ & $16,7 \%$ \\
2. & $\begin{array}{l}\text { Intensitas kontak dengan ternak kambing } \\
\text { 3. }\end{array}$ & $100 \%$ \\
& $\begin{array}{l}\text { Pemakaian alat pelindung diri pada saat } \\
\text { pemerahan }\end{array}$ & 36,7 \\
4. & Tindakan pencegahan terhadap zoonosis & $52 \%$ \\
\hline
\end{tabular}

(Sumber: Hasil kuesioner dengan melibatkan Kelompok Peternak Kambing Peranakan Ettawa Simpay Tampomas yang berlokasi di lereng Gunung Tampomas, Cimalaka, Sumedang, Jawa Barat.)

Dari aspek kontak sehari-hari peternak dengan kambing perah, enam dari tiga puluh sampel peternak menunjukkan risiko cukup tinggi untuk terinfeksi zoonosis dari hewan ternaknya akibat intensitas kontak yang sering. Di sisi lain, sejumlah sebelas peternak memiliki kebiasaan untuk melakukan pemerahan susu kambing tanpa menggunakan Alat Pelindung Diri (APD) sederhana seperti sarung tangan serta masker. Menurut Purdue University (2006) dan U.S. Department of Labor (2005), APD dapat mengurangi jumlah serta tingkat keparahan luka kecelakaan dan penyakit akibat kerja. Hal tersebut berlaku pula pada peternak kambing, dimana penggunaan sarung tangan dapat menjadi sebuah langkah pencegahan tertularnya peternak akibat darah kambing yang sakit atau cairan infeksius lainnya yang dapat masuk ke dalam tubuh peternak melalui jaringan kulit yang lembab, rusak atau membran mukosa seperti pada luka terbuka. Sedangkan penggunaan masker berguna untuk mencegah penyebaran bakal penyakit melalui udara (Playford, 2011).

Sebanyak $83,3 \%$ peternak cenderung tidak melakukan pencegahan terjadinya penyakit zoonosis. Mengenai perawatan kesehatan kambing, rata-rata $48 \%$ peternak tidak melakukan tindakan-tindakan pencegahan penyakit infeksi pada kambingnya. Penelitian yang dilakukan oleh Hartady dan Widyastuti (2018) menggambarkan bahwa peternak di daerah tersebut kurang mendapatkan cukup referensi dan pengetahuan mengenai pemeliharaan dan penanganan kambing perah sakit. Kondisi ini berpotensi meningkatkan potensi kambing terjangkit penyakit dan tidak menutup kemungkinan menyebar ke ternak lainnya atau ke peternak sebagai inang lain yang sering berinteraksi dengan kambing yang sakit tersebut (Klous et al., 2016).

\section{SIMPULAN}

Kesadaran dan pengentahuan Kelompok Tani Peternak Kambing Perah Simpay Tampomas, Kabupaten Sumedang mengenai adanya infeksi zoonosis masih kurang. Terlihat dari keseharian peternak yang masih tidak mengenakan APD saat melakukan kontak langsung dengan kambing. Selain itu, peternak juga masih belum sepenuhnya menyadari pentingnya menjaga kesehatan kambing sebagai upaya pencegahan penyakit serta terjadinya kerugian akibat kambing yang sakit seperti biaya pengobatan bahkan hingga kematian ternak. Lebih dari setengah kandang telah memiliki luas bangunan yang sesuai dengan kebutuhan jumlah kambing-kambing Ettawa yang ditampung di dalamnya. Selain itu, hampir semua setengah kandang dibangun dengan gaya panggung dan telah mencukupi kebutuhan sirkulasi udara maupun pencahayaan dalam kandang. Intervensi rutin berupa penyuluhan, konseling, dan monitoring diperlukan untuk meniadakan adanya potensi zoonosis dan mengoptimalkan hasil ternak.

\section{DAFTAR PUSTAKA}

1. Centers for Disease Control. Zoonotic Diseases. November 15, 2017. (https://www.cdc.gov/ onehealth/basics/zoonotic-diseases.html, diakses 10 November 2018).

2. Hartady, T. dan Widyastuti, R. 2018. The Influence of Experience and Confidence on The Health Management of Dairy Goat (Case Study: "Simpay Tampomas Farmer Group" Village Cilengkrang, Cimalaka District of Sumedang, West JavaIndonesia). ARSHI Veterinary Letters. 2 (3) 49-50.

3. Klous, G., Huss, A., Heederik, D., dan Coutinho, R. 2016. Human-livestock contacts and their relationship to transmission of zoonotic pathogens, a systematic review of literature. One Health. 6 (2) 65-76.

4. Playford, M. 2011. Guidelines for Veterinary Personal Biosecurity ( $1^{\text {st }}$ ed.). Australian V e t e $r$ i n a $r$ y Association. Camden NSW: Dawbuts Pty Ltd.

5. Purdue University. 2006. Personal Protective Equipment for Farmers. (https://engineering.purdue. edu/ agsafety/IRSHC/Resources/SafetySnippets/ Personal_Protecti ve_Equipment_For_ Farmers.html, diakses 10 November 2018).

6. U.S. Department of Labor. 2005. Findings from the National Agricultural Workers Survey (NAWS) 2001-2002; A Demographic and Employment Profile of United States Farm Workers Washington, DC: Author.

7. Widyastuti, R., Winangun, K., Wira, D.W., Ghozali, M., dan Syamsunarno, M.R.A.A. 2017. Tingkat pengetahuan dan pespon peternak kambing perah terhadap penyakit hewan (Studi Kasus: Kelompok Tani Simpay Tampomas Cimalaka Sumedang). Dharmakarya. 6 (2) 89-92.

8. Yunita, D., Widyastuti, R., Syamsunarno, M.R.A.A., Rasad, S.D., dan Indika, D.R. 2017. Pembagian peran dan pengambilan keputusan dalam rumah tangga peternak kambing perah di Desa Cilengkrang Kecamatan Cimalaka Kabupaten Sumedang. Jurnal Ilmu Ternak. 17 (1) 21-26. 